\title{
How Does Transformational Leadership on School Leaders Impact on Teacher Creativity in Vocational High Schools?
}

\author{
Ahmad Jauhari Hamid Ripki ${ }^{1,2, *}$, Sylviana Murni ${ }^{3}$, Mochamad Wahyudi ${ }^{4}$, Suryadi Suryadi ${ }^{1}$, \\ Burmansah Burmansah ${ }^{5}$, Ayu Wulandari ${ }^{2}$, Sisca Cletus ${ }^{6}$ \\ ${ }^{1}$ Doctoral Program in Educational Management Department, Universitas Negeri Jakarta, Indonesia \\ ${ }^{2}$ Faculty of Mathematics Education, STKIP Kusuma Negara, Indonesia \\ ${ }^{3}$ Department of Educational Management, Universitas Muhammadiyah Prof. Dr. HAMKA, Indonesia \\ ${ }^{4}$ Faculty of Information Technology, Universitas Bina Sarana Informatika, Indonesia \\ ${ }^{5}$ Department of Buddhist Education, STIAB Jinarakkhita, Indonesia \\ ${ }^{6}$ Faculty of Business Administration, Politeknik LP3I, Central Jakarta, Indonesia
}

Received June 23, 2020; Revised August 1, 2020; Accepted August 25, 2020

\section{Cite This Paper in the following Citation Styles}

(a): [1] Ahmad Jauhari Hamid Ripki, Sylviana Murni, Mochamad Wahyudi, Suryadi Suryadi, Burmansah Burmansah, Ayu Wulandari, Sisca Cletus, "How Does Transformational Leadership on School Leaders Impact on Teacher Creativity in Vocational High Schools?," Universal Journal of Educational Research, Vol. 8, No. 10, pp. 4642-4650, 2020. DOI: 10.13189/ujer.2020.081033.

(b): Ahmad Jauhari Hamid Ripki, Sylviana Murni, Mochamad Wahyudi, Suryadi Suryadi, Burmansah Burmansah, Ayu Wulandari, Sisca Cletus (2020). How Does Transformational Leadership on School Leaders Impact on Teacher Creativity in Vocational High Schools?. Universal Journal of Educational Research, 8(10), 4642-4650. DOI: 10.13189/ujer.2020.081033.

Copyright $\mathrm{C} 2020$ by authors, all rights reserved. Authors agree that this article remains permanently open access under the terms of the Creative Commons Attribution License 4.0 International License

\begin{abstract}
Background of this research was regarding the problem of the development of management in educational institutions in the aspect of learning management. Teacher creativity was an essential problem that often faced by many educational institutions. The problem of teacher creativity brought influence to the learning process, which could not be done effectively and efficiently because of lacking of competencies and skills, so that the teachers did not become creative and innovative. Many factors could increase teacher creativity, one of factors could increase was to implement the transformational leadership of the leaders in the school. The purpose of this study is to examine the impact on transformational leadership of school leaders perceived by school teachers to their creativity so that they can develop their creative behaviors to tasks, new ideas, innovations, and creations that could be potential to achieve the goals and values of the school organization well. This research used a causal survey method by using the path analysis technique. This study used the sample from 219 school teachers in 50 vocational high schools, which were selected
\end{abstract}

using the Slovin formula. The result of the study reveals that there is a positive effect between the transformational leadership of the leaders and the creativity of the teachers in schools. The results of this research indicated there is a direct and positive influence of transformational leadership on creativity. Based on the conclusions, the results of this study can be used as recommendations to the leaders of educational institutions to serve as an effort to increase the creativity of teachers in their institutions.

Keywords Transformational Leadership, Leadership, Teacher Creativity, Vocational School Teachers

\section{Introduction}

The $21^{\text {st }}$ century is the era of globalization or change that goes very fast in many sectors, including education at schools. To run a school as an organization, quality resources, one of which is creative teachers are strongly 
required to enable innovations in the effective and efficient learning process to develop. Concerning this, four competencies that must be possessed by every teacher to deal with learning in this current era include pedagogical, personal, social, and professional competencies. Besides, according to the UNICEF, four competencies are needed to develop by school teachers in the modern time, namely valuing learner diversity, supporting all learners, working with others, and personal professional development [1].

First, pedagogical competencies refer to educational and teaching qualifications. Second, personality competencies are those related to teacher' behavior, and this deals with the philosophy of life that makes teachers role models who have noble values to be emulated by students. Third, professional competences are the ability of a teacher to plan and implement the learning process, and the last, social competences are the ability of a teacher to adjust to the demands of work in certain surrounding environments in the community.

Besides, teachers of the current age are also required to be creative, in line with the demands of learning in the $21^{\text {st }}$ century, namely communication, critical thinking \& problem-solving, collaboration, and creativity \& innovation, abbreviated as 4Cs [2]. Creativity is one of the abilities that should be possessed by someone to produce something new in the form of ideas or the work different from the previous one. In creativity, there exists originality, effectiveness, freedom, and flexibility of thinking [3]. Creativity can be possessed by anyone, and it can arise from the intelligence the person has [4]. Intelligence can increase creativity, and it is based on three basic individual components, namely skills that are appropriate to their expertise, skills that follow creativity, and task motivation [5].

Some measures can be done to increase creativity, one of which is by implementing transformational leadership. Leadership concerns with influencing and motivating organizational members to contribute to achieving organizational goals [6]-[8]. Therefore, to develop teacher creativity in the $21^{\text {st }}$ century, transformational leadership can be applied. Transformational leaders are those who transform personal values to their members to support the vision and goals of the organization and create good relationships between leaders and members based on trust [9]. It enables leaders to encourage and motivate their members to make changes in organizations, and to focus on the future, to be daring to take risks, to make changes despite challenges [10]. Transformational leadership has important effects on both the individual and the organization. At the individual level, it is positively related to the creativity of its members [11].

The previous researches stated that transformational leadership of the leader affects creativity of the organization members, and it can motivate and develop the creativity of their members, so that they can contribute in the form of new suggestions, ideas and solutions with the aim to improve their organization [12]-[14]. The creativity will be increased along with the treatment of transformational leadership from the leader to their members. Members will have more confidence in their ability to be creative at work. From the explanation of the concepts and results of the previous researches the abovementioned can be concluded that transformational leadership can positively influence creativity [4], [15].

\subsection{Objectives of the Study}

The aim of this research is to obtain correct and reliable comprehension regarding transformational leadership towards teachers' creativity. This study is conducted to know: the direct and positive influence of the transformational leadership on the school principals toward teachers' creativity.

\subsection{The Hypothesis of the Study}

Based on the existing literature regarding this research, the hypothesis is H1: There is a positive and direct effect of the transformational leadership of school principals toward teachers' creativity.

\section{Theoretical Foundation}

\subsection{The Impact of Transformational Leadership on Creativity}

Transformational leadership style in fostering creativity is mediated through the creativity of themselves within an organization [16]. In the education context, the principals' transformational leadership influences on the teachers' creative behavior has an impact on the psychological safety climate [13], [17]. Transformational leadership leaders through the dimensions of intellectual stimulation increase the creativity of their followers and become skilled to solve problems [14], [18]. Furthermore, transformational leadership has a significant impact on employee creativity processes which shows that task with complexity and which can support for innovation moderate the relationship between transformational leadership and involvement of employee creativity processes [15].

Transformational leadership behavior can affect a variety of creativity. This is seen from the task of a leader basically to influence, to encourage or motivate their subordinates, including moving the creativity ability possessed by the members in the organization. This is consistent with the concept expressed that transformational leadership positively influences employee' creativity, but leaders need to pay attention to factors that can reduce creativity [4]. A leader must provide opportunities for their members to participate in decision making, and to assure members that they can fully achieve the results. Being kind 
of this leader can have a positive influence on the development of creativity [19].

\section{Literature Review}

\subsection{Creativity}

Creativity in organizations is the process of generating ideas, procedures, and new products that are beneficially carried out by individuals who work together in a unified system [20]. Besides, it is defined as a way of thinking about new ideas that are useful and have the potential to be able to contribute to individuals, groups, and organizations [21]. Other researchers state that it is a person's ability to generate new ideas that are different from previous ones and have value to solve problems [4]. Creativity can also play a role in identifying, overcoming, and solving existing problems so that they can be used in decision making [22].

In a dynamic environment, creativity is highly required to overcome an uncertain condition. It can be said that creativity is a unique approach regarding different perspectives or thoughts in generating new ideas and solving existing problems [23], [24]. This is because creative people can think abstractly, develop imagination, synthesize issues, recognize patterns, and empathize with others. Other concepts of creativity can be interpreted as a person' ability to be able to visualize, produce, and implement ideas on new concepts or associations between old ideas with new ideas to produce useful values [25]. It deals with a person' ability to combine ideas in unique ways or associate extant ideas to become up-to-the-minute ideas [19]. The process of generating ideas with new approaches or associations with the result becomes a useful product later interpreted as innovation.

In addition, ideas generated from the creative process should meet three criteria. First, creative ideas must represent something different, new, or innovative. Second, they should have the expected quality or value. Third, ingenious ideas aim to solve the problems at hand. These three features are known as the elements of creative, good, and relevant ideas [26]. Besides, three other measures also become the quality of creativity. First, creating a combination of new ideas with the existing ones. The second is exploring new ideas with structured concepts, and the last is doing transformational actions leading to changes [27].

\subsection{Transformational Leadership}

Transformational leadership is a kind of chairmanship having a broad conceptual framework for individuals and groups in a more creative and interrelated way to realize the expected organizational goals [28], [29]. It inspires members to trust leaders so that they can contribute to the achievement of organizational goals to the fullest [21].
Besides, it refers to a set of abilities possessed by a leader to be able to create a vision, predict changes, and be able to guide members in bringing about changes effectively [22], [30]. It can also be interpreted as a leader who inspires and moves their members to prioritize the interests of the organization rather than their interests [23], [31]. In other words, such leaders can inspire members of the organization, see the future with a vision, and can develop others to become a leader [25], [32].

Based on the concept of transformational leadership discussed above, it emphasizes how a leader can exert influence on members so that their members can make a difference. A leader should be able to recognize future changes, create envisaged visions, and guide these changes in a better direction.

Transformational leadership can occur when leaders make three approaches [21]. First, they increase the awareness of members about the importance of the task at hand. Second, they make their members aware of the development of their competencies. Third, they motivate members to work for the good of the organization and not just personal interests [21]. In addition to these three approaches, McShane \& Glinow suggest four components be built and provided as an understanding to members of the organization regarding the transformational leadership approach. These four aspects include developing a strategic vision, communicating the vision, modeling the vision, and building commitment to the vision [8].

In the practical application of transformational leadership, Bass divides the model of leadership into four dimensions, and this is supported by other experts. The four dimensions are the idealized influence, inspirational motivation, intellectual stimulation, and individualized consideration [10], [23], [25], [33]. First, the idealized influence means behavior reflected by leaders who show a charismatic personality shown by giving a model or role for ethical behavior, instilling pride, respect, and trust [34]. The same thing expressed by other experts about the ideal influence of idealized influence is charismatic leadership leaders who have an exemplary and ethical behavior, manifest personal values, and build a positive image of the organization and their members [35], [36]. The same idea was expressed by other researchers suggesting that the idealized influence is explained in organizations in the context of creating knowledge. The term influence not just affects the ideals, but at the highest level of morality between leaders and members of the organization, and this is what is called charismatic leaders [37].

Thus, this emotional component is built between the leader and the members. It aims to realize organizational goals and focus more on mutual interests rather than self-interest. Furthermore, the idealized influence can be said as the ability of leaders in building members' trust in their leaders, to form a basic understanding of members so that they can follow the orders in making changes to the organization. Without trust in leaders carried out by the 
members, the goals of the organization will not be effectively achieved. This idealized influence, in other words, is a role model for members of the organization, by one' high moral behavior, sacrifice personal interests, personal values, and a strong belief in achieving organizational goals [38]-[41]. Besides, a leader who has an idealized influence is characterized by their performance in instilling norms, high ethics, building loyalty, devotion, and trust, [14], making role models and taking risks [34], acting as role models [33] for its members, and in the end, improving trust in their leaders. Based on these characteristics of the idealized influence of transformational leadership, it can be concluded that a transformational leader should set an example, instill positive values, and behave consistently.

The second dimension is inspirational motivation. The motivational factors are indispensable in organizations as deals with the performance of the organizational members. While there seems to be no guarantee that motivated people are those who perform well as their performance likely depends on their competencies, which are related to training and skills at work, permanent motivation becomes really vital to improve the organizational performance of these social units. Inspirational motivation refers to a leaders' effort in motivating, inspiring, giving confidence, and convincing the confidence of members to do more than expected [14], [42]. Such motivation is caused by an organization leader to its members to achieve organizational goals by setting the organizational vision, enthusiasm, optimism, and building self-confidence [38]. Similar studies seem to agree that motivational inspiration is defined as a leader who gives enthusiasm, builds enthusiasm and optimism, and builds shared commitment and shows positive things to achieve organizational goals [43], [44].

Furthermore, inspirational motivation arises from the influence of the use of effective communication styles carried out by the leadership. This behavior articulates the importance of leaders' conveying high expectations to subordinates, inspiring, motivating them by giving meaning and challenges, presenting an optimistic outlook for the future, and creating priorities and goals to employees so they can develop a shared vision in the organization [9], [37]. These aspects surely require good communication skills because these leaders should deliver the message correctly and clearly. Thus, the important behavior of a transformational leader includes providing motivation, inspiring enthusiasm, giving hope, building optimism, confidence, enthusiasm, and the ability to show positive. In short, transformational leadership in the dimension of inspirational motivation means providing motivation, arousing enthusiasm, and giving hope.

Third, intellectual stimulation - this is done by teaching critical thinking and problem-solving in an effort to make the organization better. Intellectual stimulation refers to increasing one' ability to think in their own way about how to carry out tasks. Thus, intellectual stimulation is described as an individual' ability to be rational with their ability to think intelligently when assessing the environment, which makes him capable of generating new ideas [38]. The practice of intellectual stimulation by leaders is intended to encourage followers to think more innovatively and creatively. With this transformation, leaders provide challenges and encourage creativity [14], [33]. Intellectual stimulation also emphasizes increasing knowledge by stimulating and encouraging creativity, providing challenges, and providing information to members to be able to carry out their tasks more effectively [45].

Furthermore, transformational leaders actively seek new ideas by using new ways of doing things. Leaders demonstrate intellectual stimulation by providing motivation and providing alternative solutions so that organizational members can think of these alternatives [9]. Transformational leaders actually develop members to find innovative and creative ways to solve classic problems. Intellectual stimulation emphasizes the knowledge or intelligence of members with the aim of producing innovation in work [34]. Intellectual stimulation enhances the ability to think in unique ways and provides new ideas about problem-solving and increases skills or abilities [46]. Thus, it can be concluded that intellectually stimulated transformational leadership is based on providing challenges, arousing creativity, and increasing intelligence.

Fourth, individual considerations - transformational leaders can become trainers for their members by providing encouragement for personal progress. Good leaders are the ones who give challenging tasks, arouse thoughts, and create an atmosphere of trust. The way leaders take this approach is by providing guidance and training to their members; this is intended to add experience for members in completing work [46]. This means that leaders pay attention to individual-level needs. The members will feel delighted, enthusiastic when the components carried out by the leadership in improving individual abilities. This means signifying that members are highly considered by their leaders. In addition, the leader acts as a coach who can instruct at any time to achieve organizational goals. But what needs to be considered is the directed and communicative communication patterns with its members.

Transformational leaders must have sensitivity as individuals and respect differences between individuals. This consideration is based on the basic needs of individuals who are needed. This is like the attention of the leadership regarding the fulfillment and improvement of the needs of each individual [33], acting as a mentor [14], recognizing individual needs, and delegating tasks [9]. In other words, individual consideration includes attention, encouragement, support, coaching, guidance, and teaching leaders to members [34], [46]. Thus, it can be concluded that transformational leadership with dimensions of individual consideration is based on the attention of the 
leadership, delegation, and guidance.

\section{Methodology}

\subsection{Research Approach}

This research is a quantitative research approach applying the survey method with a causality whose focus is to assess the creativity of vocational school teachers. This research approach describes that survey research involves collecting data to test hypotheses or to answer questions about the opinions of others about a theme or problem. This survey is an instrument that functions to collect data by describing one or more characteristics of a particular population [47], [48].

\subsection{Validity \& Reliability}

Table 1. Result of Validity Test

\begin{tabular}{|c|c|c|c|}
\hline Instrument & $\mathrm{N}$ & Valid Item & Invalid Item \\
\hline Creativity & 40 & 33 & 7 \\
\hline $\begin{array}{c}\text { Transformational } \\
\text { Leadership }\end{array}$ & 40 & 35 & 5 \\
\hline
\end{tabular}

Table 2. Result of Reliability Test

\begin{tabular}{|c|c|c|c|}
\hline Instrument & Valid Item & Alpha Value & Note \\
\hline Creativity & 33 & 0,920 & Reliable \\
\hline $\begin{array}{c}\text { Transformational } \\
\text { Leadership }\end{array}$ & 35 & 0,944 & Reliable \\
\hline
\end{tabular}

\subsection{Research Instrument}

Creativity is the way of thinking to create and to develop a new idea by school teachers on their works in the learning process, with following indicators; (1) originality of ideas, (2) independence of thinking, (3) smoothness of thinking, and (4) personal flexibility.

Transformational leadership is the school principals' action to inspire the school community in order to develop and to manage the school and human resource to achieve the school goals, with following indicators; (1) idealized influence, (2) inspirational motivation, (3) intellectual stimulation, and (4) individual considerations.

The instrument used to obtain transformational leadership, and creativity data includes close-ended questionnaires with Likert scale responses. The responses cover five categories consisting of 1 for never, 2 for rarely, 3 for sometimes, 4 for frequently, and 5 for always.

\subsection{Participants}

This research was conducted in vocational high schools in Karawang Regency, West Java, Indonesia. The analysis unit in this research was the vocational high school teachers. The population was all the vocational high school teachers with a total of 483 teachers out of 50 schools, ignoring the sex and educational background. The samples were selected by using simple random sampling method by choosing the members of the population randomly. The population was homogenous that all the teachers as participants taken from public vocational schools with a large number. From the existing population, the number of samples was calculated with the Slovin formula. Therefore, the sample used in this research was 219 teachers.

\subsection{Data Collection}

To collect data in this research, a questionnaire was used for the two variables: transformational leadership (X1) and Creativity $(\mathrm{Y})$. All the questionnaires were filled in by teachers from Vocational High Schools. All the research instruments had been tested and analyzed by the validity test, and all the instruments had high reliability. Thus, all the instruments could be used in the research to collect data.

\subsection{Data Analysis}

The purpose of this research is to know the impact and influence of one variable on other variables, namely, the transformational leadership of the school principals towards school teachers' creativity. In this research was analyzed through path analysis techniques.

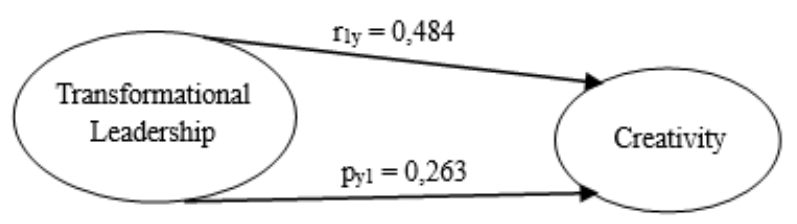

Figure 1. Structural Model of Inter-Variable

\section{Results and Discussion}

Normality Error Data Test for Estimated Creativity on Transformational Leadership ( $\mathrm{Y}$ over $\mathrm{X}_{1}$ ), based on the (Lilliefors Test), $\mathrm{L}_{\text {count }} 530.053$ and $\mathrm{L}_{\text {table }} 0.060$ were obtained. This means that the error of estimated creativity on Transformational Leadership is normally distributed. The calculation of the significance and linearity of the regression looks $\mathrm{f}_{\text {count }}$ of 66.282 the value is greater than the $\mathrm{F}_{\text {table }}$ of 3.885 if taken the real level $\alpha=0.05$. Thus it can be concluded that the regression equation of creativity on transformational leadership is very significant. From the regression linearity test, it is obtained $\mathrm{F}_{\text {table }} 0.900$, and the value is smaller than the $\mathrm{F}_{\text {count }}$ with a value of 1.377 , while the real level is $\alpha=0.05$. Therefore, the regression equation of creativity in transformational leadership shows a significant value.

After calculating the results with SPSS 20 and doing the statistical analysis, the researcher found a direct effect of 
transformational leadership on creativity. The results of this calculation are obtained from the path analysis and show a $t_{\text {count }}$ of 8.141 with a significance value of 0.000 . This is a strong reason to accept $\mathrm{Hl}$ because $\mathrm{t}_{\text {count }}$ is greater than $t_{\text {table }}(8.141>1.652)$. In other words, it can be concluded that transformational leadership has a direct and significant influence on creativity. For Standardized Coefficients Beta values of 0.484 or $48.40 \%$, this means that creativity is influenced by transformational leadership by $48.40 \%$, and the remaining 51.60 is influenced by other variables not examined in this study.

The results of these calculations are consistent with previous research, which states that transformational leadership has an essential effect on individuals and organizations. At the individual level, transformational leadership is positively related to member creativity [11]. The same notion was expressed in the results of the study, suggesting that transformational leadership can motivate and develop the creativity of members in that they can contribute to improving the organization through their suggestions, ideas, and new solutions [12].

As mentioned earlier, in transformational leadership, there are four dimensions that can influence creativity. The four dimensions cover (1) idealized influence, (2) motivation for inspiration, (3) intellectual stimulation, and (4) individualized consideration. Each of these dimensions has a value, where the idealized influence dimension has a value of $26.01 \%$, the inspiration motivation dimension contributes $25.03 \%$, the individualized consideration dimension has $24.73 \%$, and the intellectual stimulation dimension provides $24.22 \%$. Of the four dimensions, the idealized influence dimension has the highest value of all. Furthermore, based on the scores of the indicators, the highest indicator is on instilling positive values from the idealized influence dimension of 3.90, while the mean score of the three indicators of the ideal influence is 3.85 .

If seen from the scores of the transformational leadership instrument items, out of 35 statement items, statement No. 23 on the indicator of instilling positive values with the dimension of idealized influence has the highest score, which is 4.14 for the statement "the principal is enthusiastic in doing work". The statement gives the meaning that the principal gives and instills positive values such as enthusiasm at work, motivates them to do their best, and will be able to have a positive effect on teachers because these attitudes will be seen and followed by them. Based on the results of the above calculations, it can be concluded to increase teacher creativity; the principal should implement transformational leadership with the dimension of the idealized influence.

The results of the researchers' calculations agree with those of the previous study showing that there is a positive relationship between inspirational motivation, idealized influence, and individual creativity [49]. The same idea is also supported by another study, which states that the idealized influence, inspirational motivation, intellectual stimulation, individual considerations have an impact on the creativity of members, but intellectual stimulation has the highest impact of all dimensions [14]. The idealized influence on transformational leadership suggests that school principals should develop positive values, such as building insight and knowledge, instilling high commitment, behaving, friendly, being polite, prioritizing public interests rather than personal interests, working more than talking, and considering teachers as supportive coworkers, not subordinates.

Besides, the principals should provide examples to teachers regarding the development of creativity to follow. Furthermore, they are expected to have good self-confidence and have no doubt about what they do or decide. If they do not have such qualities, these values shall not be followed by teachers. A good leader is the one who always provides direction, guidance, and role models to his/her members, and the values are referred to improve teachers as the members of the school organization. This is similar to the results of a study arguing that transformational leadership has a significant effect on creativity if accompanied by a learning orientation [50]. According to Jyoti \& Dev, the application of transformational leadership will encourage its members to be able to think differently, generatively, and exploratively to produce more solutive and creative ideas. However, they also suggest that to create these thoughts, leaders applying transformational leadership should provide a learning orientation, meaning that a leader should give the opportunity for their subordinates to learn to do something that can produce contributions to the organization.

Good leaders are those who do not limit their members to develop their competence. Besides, leaders who emphasize this learning orientation can make members of the organization committed to continuous learning, keep thinking open, share knowledge to people in the organization, and unite shared understanding of the vision to achieve organizational goals. This is different from the results of research that states transformational leadership is positively related to creativity, but it should be added by the psychological empowerment by leaders to foster the creativity of their members [18]. Suifan \& Al-Janini explain that psychological empowerment is an effort to increase one' intellectual motivation. A person's motivation will increase, along with being empowered in his organization. Members of the organization will feel happy if involved in various activities or policies in the organization. This is because they feel valued, respected, and are considered to give more contributions by the organization, rather than merely carrying out regular tasks. Empowerment will make members feel lively and will be motivated to carry out their work and will eventually lead to creativity, and this is consistent with the study stating that there is a significant influence of intrinsic and extrinsic motivation on creativity [51].

This research is rather different from the results of 
previous studies, that intrinsic motivation becomes a very significant mediator between transformational leadership and employee creativity [11], [52], [53]. Transformational leadership fosters employee creativity by developing a creative work environment [16], [52], [54]. Additionally, intrinsic motivation, task complexity, self-efficacy, and support for innovation mediate the relationship between transformational leadership and the involvement of the creative process of employees [13], [15]. Principal's transformational leadership is significant to teacher creativity by involving intellectual stimulation and involvement in the decision making dimension [17].

Furthermore, based on comparison from the result of this study and the previous researches of transformational leadership of school leaders impacts to the teachers' creativity also generally happened to other countries, but there are differences which influence factors of transformational leadership characteristics that impact to the teachers' creativity. Reviewing related research studies and synthesizing them with what has been found under the study, the researchers found that there are differences between the research findings and the results of previous studies. This research found that to increase teacher creativity through transformational leadership places more emphasis on the idealized influence by leaders' instilling positive values, setting good examples, and performing self-confidence, whereas previous research studies suggest enhancing creativity through transformational leadership through the aspects of the work environment [55], intrinsic motivation [56], [57], task complexity [12], [58], self-efficacy [59], intellectual stimulation [60], decision making [12], and psychological empowerment [56].

\section{Conclusions \& Limitations}

Based on the results of the analysis and discussion, this study arrives at some conclusions. First, there is a direct and positive influence of transformational leadership on teacher creativity. The influence of transformational leadership on creativity can be seen from the four dimensions, namely the idealized influence, inspirational motivation, intellectual stimulation, and individualized consideration. Based on the findings of this study, all four dimensions influence creativity; however, the most significant or highest influence on creativity has been contributed by the ideal influence. Thus, to increase teacher creativity, school principals can implement transformational leadership by prioritizing the idealized influence dimension first, then followed by the dimensions of inspirational motivation, intellectual stimulation, and individual consideration.

As transformational leadership has a direct and positive effect on teacher creativity, school principals can implement transformational leadership to increase teacher creativity with the four-dimensional approach, namely the idealized influence, the inspiration motivation, intellectual stimulation, and individualized consideration. Transformational leadership conducted by principals is expected to focus on changing teacher behavior to be more creative, stimulating, responsible, and confident in achieving the goals set. Transformational leadership, that one that provides the opportunity for its members to always make changes, is determined to work best for the organization to achieve beyond the expected results. Thus, if transformational leadership is applied correctly, it can support the organization in meeting the expectations and respond to the needs of the teacher' creativity, so that the predetermined goals are achieved.

\section{Recommendations}

Vocational School teachers are expected to have the view that creativity in teaching is really crucial to have and develop. By having creativity in teaching, the educational goals set by the school can be achieved properly. Thus, what must be done to develop creativity is that teachers should be open-minded, accepting criticism, abandoning old and ineffective methods, updating any information on teaching, exchanging ideas with peers, solving educational problems, and participating in various training programs or workshops to improve their competencies.

Whilst for vocational school principals, the recommendations include the following items. (1) Creating a kind of Teacher Creativity Improvement (TCI) program based on the school work program created for one year such teacher in-house training, teaching method and motivation workshop, ICT program for teacher training, problem solving workshop for teacher, and etc.; (2) Communicating with other school principals at the Principal Work Meeting (PWM) for sharing information about efforts in improving teacher creativity in addition to creating discussion forums (FGD) for creative teachers periodically by inviting educational experts; and (3) Creating a pleasant school environment, by providing facilities or infrastructure that can improve teachers' enthusiasm in carrying out the teaching process and creating a comfortable atmosphere for teachers in the school environment.

\section{Acknowledgments}

The researchers would like to express their greatest gratitude to the West Java Provincial Education Office, Karawang Regency Education Office, and participating principals of Private Vocational Schools for the support. Great appreciation also goes to LPDP as a scholarship provider that has provided funding to conduct this research. 


\section{REFERENCES}

[1] J. Hollenweger and E. Krompák, Teacher Manual: School-based and classroom-based activities to support all learners. Skopje, Makedonia: UNICEF, 2018.

[2] Tavis D. Jules and C. Kelly Sundberg, "The internationalization of creativity as a learning competence," Glob. Educ. Rev., vol. 5, pp. 35-51, 2018.

[3] M. A. Runco and G. J. Jaeger, "The standard definition of creativity,” Creat. Res. J., vol. 24, no. 1, pp. 92-96, 2012.

[4] S. P. Robbins and T. A. Judge, Organizational behavior, Seventeent. United States: Pearson Education, 2017.

[5] H. Y. Y. A, T. Sulaiman, and R. Baki, "The role of multiple intelligences and creativity In students' learning style," Int. J. Sustain. Dev., vol. 02, no. 08, 2011.

[6] R. L. Daft, Management, Eight Edit. South-Western: Thomson, 2008.

[7] J. L. Gibson, J. M. Ivancevich, J. James H. Donnelly, and R. Konopaske, Organizations, behavior, structure, processes, Fourteenth. New York: McGraw-Hill/Irwin, 2009.

[8] Steven McShane and M. Von Glinow, Organizational behavior: Emerging knowledge and practice for the real word, Fifth edit. New York: McGraw-Hill/Irwin, 2010.

[9] M. O. Cetina and F. S. F. Kinik, "An analysis of academic leadership behavior from the perspective of transformational leadership," Procedia - Soc. Behav. Sci. Sci., vol. 207, pp. $519-527,2015$.

[10] C. Niphadkar and A. M. Kuhil, "The New age of Transformational Leadership: Evolution and Attributes," Int. J. of Scientific Eng. Res., vol. 8, no. 6, pp. 546-555, 2017.

[11] L. Gumusluoglu and A. Ilsev, "Transformational leadership, creativity, and organizational innovation," J. Bus. Res., vol. 62, pp. 461-473, 2009.

[12] K. Teymournejad and R. Elghaei, "Effect of transformational leadership on the creativity of employees: An empirical investigation," Eng. Technol. Appl. Sci. Res., vol. 7, no. 1, pp. 1413-1419, 2017.

[13] Q. Zhou and W. Pan, "A cross-level examination of the process linking transformational leadership and creativity: The role of psychological safety climate," Hum. Perform., vol. 28, pp. 405-424, 2015.

[14] R. Ravikumar, "Transformational leadership and follower's creativity: Does follower's sex matter?," J. Humanit. Soc. Sci., vol. 22, pp. 32-38, 2017.

[15] M. Mahmood, M. A. Uddin, and L. Fan, "The influence of transformational leadership on employees' creative process engagement: A multi-level analysis," Manag. Decis., 2018.

[16] S. Mittal and R. L. Dhar, "Transformational leadership and employee creativity: Mediating role of creative self-efficacy and moderating role of knowledge sharing," Manag. Decis., vol. 53, no. 5, pp. 894-910, 2015.

[17] A. G. K. Abdullah, Y.-L. Ling, and Z. B. S. A. Kader, "Principal's transformational leadership And teacher's creativity: Mediating role of self-efficacy," Manag. Res. J., vol. 6, no. 1, pp. 1-7, 2016.
[18] T. S. Suifan and M. Al-Janini, "The relationship between transformational leadership and employees' creativity in the jordanian banking sector," Int. Rev. Manag. Mark., vol. 7, no. Issue 2, pp. 284-292., 2017.

[19] S. P. Robbins and M. Coulter, Management, Eleventh E. New Jersey: Pearson Education, 2012.

[20] S. Parjanen, "Experiencing Creativity in the Organization: From Individual Creativity to Collective Creativity," Interdiscip. J. Information, Knowledge, Manag., vol. 7, 2012.

[21] J. M. George and G. R. Jones, Understanding and managing organizational behavior, Sixth Edit. New Jersey: Prentice Hall, 2012.

[22] R. w. Griffin and G. Moorhead, Organizational behavior managing people and organizations, 11th ed. South-Western: Cengage Learning, 2014.

[23] J. John R. Schermerhorn, J. G. Hunt, R. N. Osborn, and M. Uhl-Bien, Organizational behavior, 11th Editi. United States: John Wiley \& Sons, Inc, 2010.

[24] F. Luthans, Organizational Behavior: An Evidence-Based Approach, 12th ed. New York: McGraw-Hill, 2011.

[25] D. Hellriegel, J. Slocum, and J. W. S. Jr, Organizational behavior. United States: Cengage Learning, 2011.

[26] J. C. Kaufman and R. J. Sterberg, The Cambridge Handbook of Creativity. 2010.

[27] E. Sefertzi, "dissemination of innovation and knowledge management techniques," in Creativity Research Journal, 2000, pp. 1-20.

[28] A. Montuori and G. Donnelly, "Handbook of Personal and Organizational Transformation," in Transformative Leadership, 2017, pp. 1-33.

[29] A. R. A. Ghani, A. Fatayan, I. Yatri, L. Qodariah, B. Bunyamin, and B. Burmansah, "Evaluation of school-based management implementation (sbm) in madrasah jakarta," Talent Dev. Excell. J., vol. 12, no. 1, pp. 3490-3511, 2020.

[30] A. J. H. Ripki, "Relationship between motivation and job satisfaction with performance," in 1st International Conference on Technology and Educational Science (ICTES 2018), 2019, pp. 56-62.

[31] B. Burmansah, R. Rugaiyah, M. Mukhtar, S. Nabilah, A. J. H. Ripki, and A. Fatayan, "Mindful leadership: The ability of the leader to develop compassion and attention without judgment - A case study of the leader of buddhist Higher education Institute," Eur. J. Educ. Res., vol. 9, no. 1, pp. 5165,2020

[32] N. Karnati, S. Suryadi, B. Burmansah, and A. Fatayan, "Improving the effectiveness of employee performance: The value of a series of influence factors," Int. J. Innov. Creat. Chang., vol. 12, no. 8, pp. 35-52, 2020.

[33] J. A. Odumeru and I. G. Ogbonna, "Transformational vs. Transactional Leadership Theories: Evidence in Literature," Int. Rev. Manag. Bus. Res., vol. 2, no. 2, pp. 355-361, 2013.

[34] M. G. O. Ogola, D. Sikalieh, and T. K. Linge, "The Influence of Idealized Influence Leadership Behavior on Employee Performance in Small and Medium Enterprises in 
Kenya,” Eur. Int. J. Sci. Technol., vol. 6, no. 3, pp. 47-62, 2017.

[35] F. Cavazotte, V. Moreno, and J. Bernardo, "Transformational Leaders and Work Performance: The Mediating Roles of Identification and Self efficacy," Brazilian Adm. Rev., vol. 10, no. 4, pp. 490-512, 2013.

[36] S. K. Chebon, W. K. Aruasa, and L. K. Chirchir, "Effect Of Inspirational Motivation And Idealized Influence On Employee Performance At Moi Teaching And Referral Hospital, Eldoret, Kenya," Int. J. Bus. Soc. Sci., vol. 10, no. 7, pp. 131-140, 2019.

[37] L. Ngaithe, G. K'Aol, P. Lewa, and M. Ndwiga, "Effect of Idealized Influence and Inspirational Motivation on Staff Performance in State Owned Enterprises in Kenya," Eur. $J$. Bus. Manag., vol. 8, no. 30, pp. 6-13, 2016.

[38] R. A. M. Abazeed, "Impact of Transformational Leadership Style on Organizational Learning in the Ministry of Communication and Information Technology in Jordan," vol. 9, no. 1, pp. 118-129, 2018.

[39] W. Jiang, X. Zhao, and J. Ni, "The Impact of Transformational Leadership on Employee Sustainable Performance: The Mediating Role of Organizational Citizenship Behavior," Sustainability, pp. 1-17, 2017.

[40] U. A. Okoth, "Transformational leadership practices in curriculum implementation (environmental education) in secondary schools in siaya county, kenya," Eur. Sci. J., vol. 14, pp. 320-331, 2018.

[41] B. Burmansah, R. Rugaiyah, and M. Mukhtar, "Mindful leadership: the ability of leader to establish connection to others , community , and deal with changes skillfully - a case study of buddhist higher education institute leader," Int. e-Journal Educ. Stud., vol. 4, no. 7, pp. 133-149, 2020.

[42] B. Burmansah, R. Rugaiyah, and M. Mukhtar, "A case study of mindful leadership in an ability to develop focus, clarity, and creativity of the buddhist higher education institute leader," Int. J. High. Educ., vol. 8, no. 6, pp. 57-69, 2019.

[43] I. Simic, "Transformational Leadership - The Key To Successful Management Of Transformational Organizational Changes," Econ. Organ., vol. 1, no. 6, pp. 49-55, 1998.

[44] M. M. Yaslioglu and N. Selenay Erden, "Transformational Leaders in Action: Theory Has Been There, But What About Practice," Istanbul University, pp. 42-53, 2018.

[45] Nedelcu Anca, "transformational approach to school leadership: Contribution to Continued improvement of education," Chang. Leadersh., vol. 17, pp. 237-244, 2013.

[46] F. Ahmad, T. Abbas, S. Latif, and A. Rasheed, "Impact of Transformational Leadership on Employee Motivation in Telecommunication Sector," J. Manag. Policies Pract., vol. 2, no. 2, pp. 11-25, 2014.

[47] J. W. Creswell and J. D. Creswell, Research design: qualitative, quantitative, and mixed methods approaches, 5 th ed. Thousand Oaks, United States: SAGE Publications Inc, 2018.

[48] U. Sekaran, Research methods for business: a skill-building approach, 7th ed. New York, United States: John Wiley \& Sons Inc, 2016.

[49] H. Gunduz, Cekmecelioglua, and G. K. Ozbagb, "Leadership and Creativity: The Impact of Transformational Leadership on Individual Creativity," Procedia - Soc. Behav. Sci., vol. 235, pp. 243 - 249, 2016.

[50] J. Jyoti and M. Dev, "The impact of transformational leadership on employee creativity: the role of learning orientation," J. Asia Bus. Stud., vol. 9 iss 1, pp. 78-98, 2015.

[51] M. Azeem, A. Hayat, R. Nawaz, H. M. Sajjad, and M. Ali, "The Effect of Motivation on Employee Creativity: Evidence from NGO Sector in Southern Punjab, Pakistan," Int. J. Bus. Manag., vol. 7, no. 2, pp. 161-166, 2019.

[52] Mojgan Afshari, S. Siraj, M. F. A. Ghani, and M. Afshari, "Leadership and creativity," Aust. J. Basic Appl. Sci., vol. 5, no. 10, pp. 1591-1594, 2011.

[53] T. S. Suifan, A. Bahjat, Abdallah, and M. Al Janini, "An integrated model of job involvement, job satisfaction and organizational commitment: A structural analysis in jordan's banking sector," Manag. Res. Rev., vol. 41 Issue:, pp. 113$132,2018$.

[54] B. Burmansah, B. Sujanto, and M. Mukhtar, "The Teachers' Affective Commitment Through The Effects of Quality of Work Life and Job Involvement In The School," in Asia Proceedings of Social Sciences, 2019, vol. 4, no. 1, pp. 1720.

[55] S. Safdar and S. Liu, "Effect of transformational leadership on employee creativity through organizational commitment," Int. J. Manag. Stud. Res., vol. 6, no. 1, pp. 61-67, 2018.

[56] Y. Kallapadee, K. Tesaputa, and K. Somprach, "Strengthening the creative transformational leadership of primary school teachers," Int. Educ. Stud., vol. 10, no. 4, p. 179, 2017.

[57] S. Andriani, N. Kesumawati, and M. Kristiawan, "The influence of the transformational leadership and work motivation on teachers performance," Int. J. Sci. Technol. Res., vol. 7, no. 7, pp. 19-29, 2018.

[58] M. Stump, O. Zlatkin-Troitschanskaia, and O. Mater, "The effects of transformational leadership on teachers' data use," J. Educ. Res. Online, vol. 8, no. 3, pp. 80-99, 2016.

[59] A. G. K. Abdullah, Y.-L. Ling, and Z. B. S. A. Kader, "Principal's transformational leadership and teacher's creativity: Mediating role of self-efficacy," Manag. Res. J., vol. 6 , no. 1, pp. 1-7, 2016.

[60] K. D. Anderson, "Transformational teacher leadership in rural schools," Rural Educ., vol. 29, no. 3, pp. 8-17, 2018. 